\title{
Disintegrin and Metalloproteinase Domain-Containing Protein 12
}

National Cancer Institute

\section{Source}

National Cancer Institute. Disintegrin and Metalloproteinase Domain-Containing Protein

12. NCI Thesaurus. Code C96039.

Disinteg rin and metalloproteinase domain-containing protein 12 (909 aa, $100 \mathrm{kDa}$ ) is encoded by the human ADAM12 gene. This protein plays a role in proteolysis, signaling and cell adhesion. 